\title{
Innovations in the Procedural Laws on Rape and Other Sexual Offences in Nigeria
}

\author{
${ }^{* 1}$ HENRY A. AKUCHIE, RSF, MIFE. \\ IBRAHIM BADAMASI BABANGIDA UNIVERSITY \\ LAPAI, NIGER STATE, NIGERIA
}

\begin{abstract}
:
The improvements made in the procedural law in Nigeria, on issues of evidence, corroboration, compensation of victims, protection of victims and witnesses are $\mathrm{x}$-rayed and appreciated in this paper. The laws of procedure admiringly considered in this paper are the Evidence Act 2011 (as amended) and the Administration of Criminal Justice Act, 2015. This paper also takes a look at how the improvements made in such Nigerian substantive and procedural legislations as the Child's Rights Act, 2003, the Violence Against Persons Act, 2015, Trafficking in Persons (Prohibition), Enforcement and Administration Act, 2015, align with the Rules of Procedure and Evidence with the International Criminal Tribunal for the former Yugoslavia (the ICTY) and the Rules of Procedure and Evidence with the International Criminal Tribunal for Rwanda (ICTR) as they relate to sexual assault.
\end{abstract}

Keywords: Mens Rea, Actus Reus, Defilement, Prosecutrix, Corroboration, Penetration

DOI: $10.7176 / \mathrm{JLPG} / 87-11$

Publication date:July $31^{\text {st }} 2019$

\section{Introduction -}

With the emergence of new dimensions to sexual offences in Nigeria, especially rape and sexual exploitation, the two major federal legislations enforced against the crimes of sexual violence, among other criminal offences were the Penal Code and the Criminal Code Acts. These Codes were applicable to Northern and Southern Nigeria respectively. However, they were found not to adequately address the new dimensions to sexual offences, especially rape and sexual exploitation, and hence the need for further legislations became necessary and compelling.

Besides the improvements of the substantive laws on rape, sexual exploitation and other sexual offences, the Nigerian Criminal Justice System has also recorded some remarkable improvements on the laws of procedure guiding prosecution and adjudication of criminal cases, including rape and other sexual offences. The improvements are as they relate to corroboration in sexual offences, questions tending to x-ray past sexual life of victims of rape and other sexual violence, protection of victims of sexual violence and witnesses in the course of trial, award of compensation to victims and their estate as part of the criminal proceedings and restitution.

The achievements which are legislative interventions are recorded in the Evidence Act, 2011 (as amended) and the Administration of Criminal Justice Act, (ACJA), 2015. The improvements are examined as thus:

\section{Proof, Issues of Evidence and Corroboration in Rape and Other Sexual Offences -}

Actus Reus, Mens Rea: To establish a case of rape against an accused person or a defendant, it must be shown by evidence that the person accused of rape actually had sexual intercourse with the victim without the real or genuine consent of the victim. This is the actus reus, meaning the physical element of the offence. To establish the mens rea, which is the mental element or the guilty-intention-element of the offence, the prosecution must also show by evidence that the offender had the intention to have such non-consensual sexual intercourse knowing or having reasons to know that the victim did not give free or genuine consent to the intercourse and/or cared less as to whether the victim consented to or freely permitted the intercourse. In other words, it must be shown by evidence that the accused rapist intentionally cared less about the free consent of the victim and went ahead with the sexual intercourse with the victim.

The actus reus and mens rea of the offence of rape are present in the insight given by the Supreme Court in the case of Popoola v. State ${ }^{2}$ when the court said: "........., a man will be said to have committed rape if he had unlawful sexual intercourse with a woman or girl who at the time of the intercourse does not consent to it; and at the time, he knows that she does not consent to the intercourse or he is reckless as to whether she consents to it.

As noted by the Supreme Court in the case of Ogunbayo v. State, ${ }^{3}$ the degree or depth of penetration of the vagina of the victim with the penis of the rapist does not matter. Once it is shown that there was penetration,

B.Sc., M.A (Houston), JD (San Jose), LL.M (Virginia), LL.D (South Africa), Senior Lecturer, IBB

University, Lapai, Niger State, Nigeria, Former Adjunct Senior Lecturer, Faculty of Law, Baze University, Abuja, Nigeria.

(2013) 17 NWLR (pt. 1382) p. 96.

(2007) All FWLR (pt 365), 408 at 430 
even the slightest penetration without the free or genuine consent of the victim, the offence is committed.

Interestingly, with the general position of the law on rape as contained in Part 1, Section of the Violence Against Persons Prohibition (VAPP) Act, 2015 which accommodates the current realities on issues of rape by recognizing females as persons capable of committing the offence of rape and prohibiting the non-consensual penetration of not only the vagina but also the anus, and mouth of another person by the use of not only the penis, but also any other part of the body like hands, fingers and/or other objects manipulated by third parties. The offence of rape would be held to have been committed once there is penetration, even the slightest penetration of the vagina, or the mouth or the anus with penis, or with any other part of the body like the hands, the fingers or with any other object manipulated by any other person, whether male or female without the free or genuine consent or permission of the person whose vagina, anus or mouth is penetrated.

With respect to the sexual offence of indecent assault, it must also be shown by evidence that the accused person or the defendant intentionally and actually touched the victim indecently knowing or having reasons to know that the victim did not give consent to the indecent touch or cared less about the consent of the victim. More specifically, the prosecution must show by evidence that the accused committed the act of indecency or of gross indecency upon the person of another, and that other person did not consent to the act, or that he/she compelled that person by use of force or threats to join in the commission of the indecent or grossly indecent act. ${ }^{1}$

For the issue of unnatural offence, the prosecution must prove that the accused had carnal intercourse with a man, woman or animal; that such intercourse was against the order of nature; that the accused did the act voluntarily or without compulsion, and that there was penetration. ${ }^{2}$ Notably, by the reading of section 214 of the Criminal Code Act and Section 284 of the Penal Code, consent is not a defence to a charge for having carnal knowledge against the order of nature. A voluntary act of a person accused of committing unnatural offences constitutes the offence. In cases of sexual exploitation, it must also be established by evidence that the alleged offender intentionally and actually subjected the victim to practices or acts of sexual exploitation, knowing or having reasons to know that the victim of the sexual exploitation did not freely consent to the sexual exploitation.

It is however very important to note that the requirement that the guilty intention or the mens rea of the accused person or the defendant must be established as a pre-condition to securing a conviction for an alleged sexual offence does not apply to the extent of establishing the adamancy or carelessness of the accused person as to the consent of the victim in cases where the liability in the relevant law is strict and does not admit the consent of the victim as a defence.

Therefore, in cases of defilement under the Criminal Code Act and the Penal Code Act and in cases of rape under the Child's Rights Act where the victims are deemed in law to be incapable of giving consent to sexual intercourse, the prosecutor does not have the duty and is not required to prove the guilty intention of the offender. This is more so, and particularly in the context or to the extent of showing the carelessness or recklessness of the accused person as to the consent of the victim. The same could be said of sexual abuse, like indecent assault and other forms of sexual abuse and exploitation under the Child' Rights Act because a child who deemed in law to lack the capacity to give consent to sexual intercourse cannot be expected to be held by the same law to be capable of giving consent to other forms of sexual violence.

Under the common law, evidence of lack of consent to sexual intercourse was expected to manifest with facts of actual utmost struggle and active resistance such as the show of bruises, presentation of torn clothes, pants, and other under-wears. This requirement for proof of "facts against the will of the victim" to be shown by evidence of actual fight has given to any reliable fact(s) to show absence of genuine consent as a result of force, actual harm, threat or fear of harm, intimidation, fraud or misrepresentation as the nature of the act, misrepresentation as to the identity of the husband of the victim, drugging or intoxication of the victim. ${ }^{3}$

Also worthy of note is the requirement of the law that the standard of proof in all criminal offences, including all sexual offences is proof beyond reasonable doubt. ${ }^{4}$ In Sowemimo v. State, ${ }^{5}$ the court explained that "proof beyond reasonable doubts connotes proof that has attained that level of certainty, credibility and assuredness which leaves the court without any vestige of lingering doubts regarding the culpability or otherwise of the accused person and with regard to the particular offence with which he has been charged". 6

It is submitted that the improvements in the current positions of both the substantive and procedural laws, especially the removal of the challenge of obtaining corroborated evidence and the creation of strict liability offences on rape and defilement in some laws will reduce the stress of meeting the requirement of proof beyond reasonable doubt.

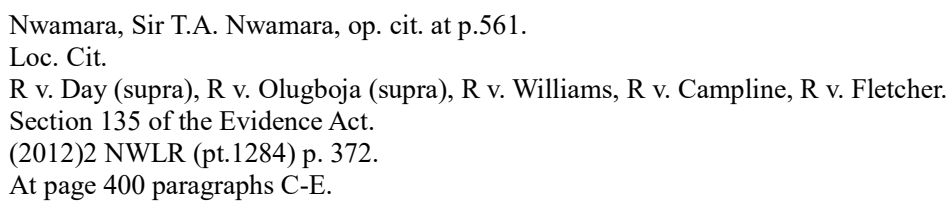




\section{Corroboration -}

Corroboration is an independent testimony or evidence from an independent witness (being a witness different from the complainant or victim or prosecutrix) which attests to, supports, strengthens or confirms the truth or the veracity of the testimony or evidence of the complainant in some material particular. In the case of Ali v. State, ${ }^{l}$ the court explained that "corroboration means no more than evidence tendered to confirm, support and strengthen other evidence sought to be corroborated."

\section{Corroboration on Sexual Offences Under the Old Evidence Act ${ }^{2}$}

Section 179(5) of the old Evidence Act of 1990 and 2004, provided and insisted that a person shall not be convicted of certain sexual offences with or upon the uncorroborated testimony of one witness. This meant that a person accused of those certain sexual offences cannot be convicted by relying only on the testimony or evidence of only one person, usually the complainant even when the testimony or evidence of the one person is believable or is indeed believed to be the truth; meaning further that there must be a materially implicating testimony of another witness in addition to the testimony of the one person, in most cases, the complainant before an accused person can be convicted of the offence. Those certain sexual offences under the Criminal Code Act were: defilement of girls under 13 years of age, contrary to section 218; defilement of girls between ages 13 and 16 years and idiots, contrary to section 221; procuration of a girl under 18 years of age to have unlawful carnal connection with any other person or persons, contrary to section 223; and procuration and defilement of women by threats, or fraud or administering drugs, contrary to section 224. For the Penal Code, the offences were: procuration of minor girl, contrary to section 275 , and having sexual intercourse with a girl under 14 years of age, contrary to section $282(1)(\mathrm{e})$.

For other sexual offences such as rape, indecent assault and other forms of sexual violation not specifically mentioned in the codes, corroboration is not required as a matter of statutory law requirement but the courts regard or consider it unsafe to convict without corroboration and observe the practice of warning itself on the danger of conviction without corroboration and in most cases, insisted on corroboration. Also, a strict observance of the rule on the court to warn itself on the danger of convicting for a sexual offence like rape without corroboration required that failure to give such warning provides a ground to quash the conviction on appeal.

Clearly, in the case of Sambo v. State ${ }^{3}$ the Supreme Court stated that it is the law that before the prosecution can secure conviction for the offence of rape, the evidence of the prosecutrix (the victim of the rape) must be corroborated in some material particular that sexual intercourse did take place and that it was without her consent. ${ }^{4}$ It is submitted that the law as stated by the Court is not statutory law or any law made by the legislature as such requirement is not found in any statute book. The law is rather a precautionary practice of the court sustained by the unwillingness of the Courts to convict a person prosecuted for rape without corroboration.

The foregoing submission that corroboration is not a statutory requirement but only a practice of courts finds it clear in a number of Supreme Court cases including the cases of Ogunbayo v. State ${ }^{5}$, and Iko v. State ${ }^{6}$. In Ogunbayo v. State, the Court stated the principle clearly in the following elucidations:

"Corroboration of evidence is not required except where the law demands it. Evidence of corroboration of the evidence of the victim in a rape case is not required as a matter of law, but it is required in practice. In other words, in the cases of a sexual character, it is eminently desirable that the evidence of the complainant should be strengthened by other evidence implicating the accused person in some material particular. It is however not a rule of law that an accused person in a charge of rape cannot be convicted on the uncorroborated evidence of the prosecutrix"'?.

Again, at the risk of repetition, but for the sake of emphasis, the Court in that same case proceeded to say:

"There is no statute foisting on the prosecution a duty to provide evidence of corroboration before an accused person can be convicted for the offence of rape. Section 350 of the Criminal Code Act, Cap 77, Laws of the Federation of Nigeria, 1990 which is similar to the States Criminal Codes, does not provide that evidence of corroboration is necessary for conviction. And the Criminal Code specifically provides for offences where corroboration is necessary. Rape is not one of such. The above apart, neither the Evidence Act nor the Criminal

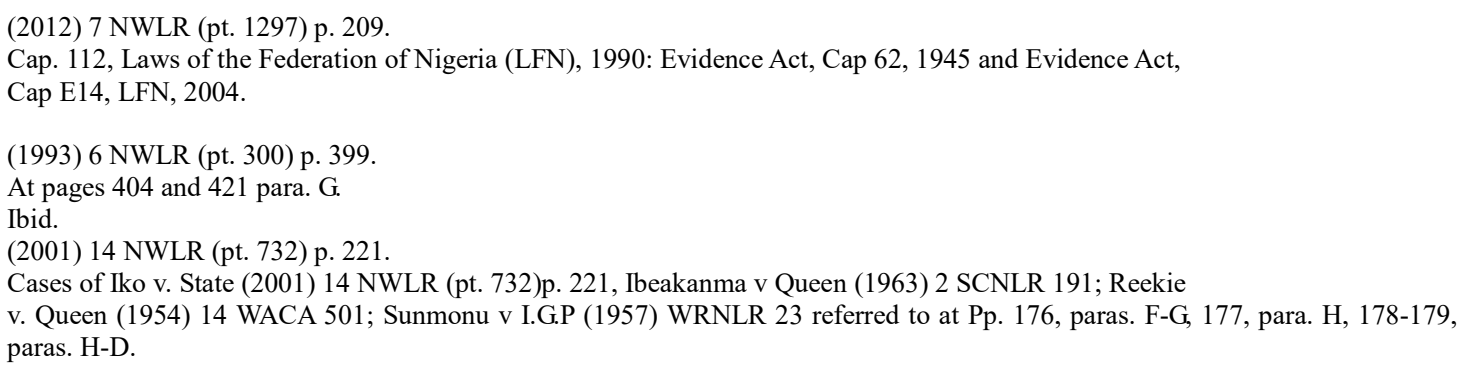


Procedure Act or Code provides for corroboration in the offence of rape. "'

Notwithstanding the clear appreciation of the non-statutory requirement of evidence of corroboration, the Courts have continued to look for corroboration in rape cases. In Ogwudiegwe v. State, ${ }^{2}$ the Supreme Court held that the offence of rape, in order to secure a conviction, corroboration of the evidence of the complainant implicating the accused is not essential, but a Judge must warn himself of the risk of convicting on the uncorroborated evidence of the complainant.

On the nature of corroborative evidence capable of grounding conviction on a charge of rape, the Court in the same case of Sambo v. State stated that a piece of evidence offered as corroboration of testimony of one witness to ground conviction for the offence of rape must be:

(a) Cogent, compelling, and unequivocal as to show without more that the accused committed the offence charged;

(b) An independent evidence which connects the accused with the offence charged; and

(c) Evidence that implicates the accused in the commission of the offence charged. ${ }^{3}$

Recently in the case of Ezigbo v. State ${ }^{4}$, the Supreme Court also stated that the nature of corroboration required in respect of the offence of rape is evidence which tends to show that the story of the prosecutrix (that is, the victim of the rape) that the accused committed the crime is true. ${ }^{5}$ Also that the nature of corroborative evidence and relevant considerations in determining whether one evidence is corroborative of another need not consist of direct evidence that the accused committed the offence charged, nor need it amount to a confirmation of the whole account given by the witness/prosecutrix but that it must however, corroborate the said evidence in some respects material to the charge in question and that corroborative evidence must in itself be a completely credible evidence.

Also that in considering whether some evidence is corroborative of some other, the court must take all the little items of the former together and consider whether they add up to corroboration as a whole. ${ }^{6}$ This shows that despite the absence of statutory requirement for corroboration in cases of rape, the Courts are in the practice of insisting on corroboration though varying their required corroborative material particulars to suit the peculiar circumstances of a given case.

\section{Evidence of A Child In Rape and other Cases of Sexual Violence -}

Experience has shown that issues of admissibility of the evidence of a child in rape cases are more complicated than when it involves adults. This is a result of the rules on corroboration arising from the practice of Courts insisting on corroboration in rape cases and the statutory requirement of the Evidence Act on the admissibility of the evidence of a child as contained in Sections 175 and 209(1)-(3) of the Evidence Act, 2011 which were sections 155 and 183 of the old and repealed Evidence Act, Cap E14, LFN, 2004.

By Section 175 of the Evidence Act, 2011 which was section 155 of the old and repealed Evidence Act, a child is competent to testify or give evidence in court and the evidence of a child is admissible unless the court considers that by the reason of the tender years of the child, he/she is prevented from understanding the questions put to him/her or cannot by the same reason of tender age, give rational answers to the questions put to him/her.

Section 209(1) of the Evidence Act, 2011, provides for the conditions under which a child of less than 14 years old can give unsworn evidence. Thus, under Section 209(1) of the Evidence Act, 2011, provides that where a child who is not up to 14 years of age is brought before the court to give evidence, such child shall be allowed to give evidence without being sworn or asked to give evidence on oath or under affirmation but this shall only happen if the court is of the opinion that such child of less than 14 years of age has sufficient intelligence to justify the reception of his/her evidence and understands the duty of speaking the truth.

In other words, where a child who has not attained the age of 14 years is in court to testify, and the court is of the opinion that the child does not possess sufficient intelligence to justify the reception of his/her evidence and does not understand the duty of speaking the truth, the child shall not be allowed to give evidence. This is because, on the strength of Sections 175 and 209(1) of the Evidence Act and the case of Sambo v. State ${ }^{7}$, wherein section 155 and 183(1) of the repealed Evidence of 1990 which had similar provision with section 175 and 209(1) of the Evidence Act, 2011 were applied, a child and indeed any witness who does not understand the duty of speaking the truth and does not have the sufficient intelligence to understand the questions put to him/her and also give rational answers to them and justify the reception of such evidence shall not be competent to testify and shall not have any business being in court to testify in the first place.

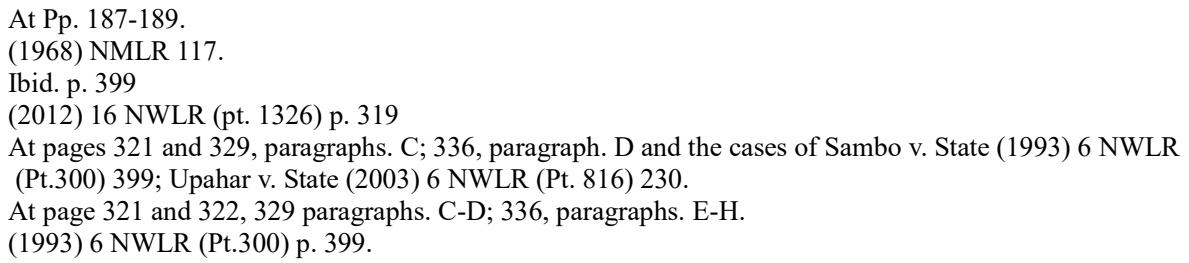


In order to satisfy itself that a child of less than 14years of age who is in court to give evidence has sufficient intelligence to justify the reception of his/her evidence and understands the duty of speaking the truth as a pre-condition for allowing such a child give an unsworn evidence or give evidence without affirmation, the court is required to carry out a preliminary investigation and be satisfied that the child:

(a) Understands the duty of speaking the truth;

(b) Is possessed of sufficient intelligence to be able to understand the questions put to him/her to justify the reception of his/her evidence.

These requirements are slightly different and could be less burdensome for the child and the court to meet than the requirements under Section 183 of the Evidence Act, Cap 112, LFN, 1990 under which the Supreme Court in the case of Sambo v. State ${ }^{1}$, stated that the court shall carry out preliminary investigation and be satisfied that the child:

(a) Understands the nature of an oath;

(b) Knows the duty of telling the truth as well as the consequences of telling a lie, and;

(c) Possessed of sufficient intelligence to be able to understand the questions put to him to satisfy the reception of his evidence. ${ }^{2}$

The procedure for reception of unsworn or un-affirmed evidence from a victim who is less than 14 years old requires that the court shall not only state in the record of proceedings its conclusion as to whether the child meets the requirement of (a) understanding the duty of speaking the truth, and (b) having sufficient intelligence to be able to understand the questions put to him/her to justify the reception of his/her, the trial court must also state in its record of proceedings how it came into the conclusion. ${ }^{3}$

The legal effect is that where the trial court fails to carry out the preliminary investigation or inquiry envisaged by sections 175 and 209 of the Evidence Act, 2011 which are almost similar to Sections 155, 180, 181, 182 and 183 of the old and repealed Evidence Acts of 1990 and 2004, before taking the unsworn or un-affirmed evidence of a child or an infant, such failure is not a mere irregularity which can be waived, but rather a fundamental irregularity which makes the court to disregard evidence so received and regard it as worthless. Therefore no conviction can be based on it. ${ }^{4}$ By Section 209(2) of the Evidence Act, 2011, a child who has attained the age of 14 years shall, subject to Sections 175 and 208 of the Evidence Act give sworn evidence in all cases. Thus, Section 209(2) of the Evidence Act, 2011 provides the condition under which a child can give evidence in court under oath in all cases, including in cases of rape other cases of sexual violence and that is only when the child has attained 14 years of age.

As earlier noted; Section 175 of the Evidence Act, 2011, which section 209(2) is subject to, is on the capacity of a child to understand the questions put to him/her in court and also give rational answers to the questions. The other section, being section 208 to which section 209(2) is also subject provides:

Section 208(1) "Any court may on any occasion, if it thinks it just and expedient, receive the evidence, though not given upon oath, of any person declaring that the taking of any oath whatsoever is, according to his religious belief, unlawful, or who, by reason of want of religious belief ought not, in the opinion of the court, to be admitted to give evidence upon oath."

Section 208(1) "The fact that in any case evidence not given upon oath has been received, and the reasons for the reception of such evidence, shall be recorded in the minutes of the proceedings"

By Section 209(3) of the Evidence Act, 2011, a person shall not be liable to be convicted for an offence including sexual offences unless the testimony admitted by virtue of subsection (1) of section 208 and given on behalf of the prosecution is corroborated by some other material evidence in support of such testimony implicating the defendant.

A reading of Sections 209(2) and 209(3) of the Evidence Act, 2011 shows that while Section 209(2) dealing on sworn evidence or evidence on oath of a child does not require corroboration; section 209(3) which refers to Section 209(1) dealing on unsworn evidence of a child requires corroboration. It would therefore be expected that as a matter of statutory requirement, a person accused of rape or any other sexual offence may be convicted on cogent evidence on oath of a child without corroboration. However, as earlier noted, the Courts in keeping with their near traditional practice of requiring corroboration in all cases of rape and other sexual violence will almost always warn themselves that it is unsafe to convict without corroboration and may insist on corroboration of not only unsworn evidence, but also sworn evidence of a child as a pre-condition to securing conviction even when corroboration of sworn evidence of a child and of any competent witness is not a matter of statutory requirement.

Furthermore, a sworn evidence of a child and a sworn evidence of an adult may constitute corroboration to




sworn or unsworn evidence of another child or an adult. However, such corroborating evidence must implicate the accused person in some material particular ${ }^{1}$. Although an evidence on oath or sworn evidence of a child may constitute corroboration to an unsworn evidence of another child, the court is required to warn itself of the danger or risk in relying on evidence of young persons, boys and girls alike in examining the corroboration. This was the position of the court in Queen $v$. Ekelagu ${ }^{2}$. On this point also, an unsworn evidence of a child cannot serve as or provide corroboration to another unsworn evidence of another child ${ }^{3}$. This was clearly stated in Sambo v. State 4 as follows:

"The evidence of the victim (P.W3) was demining against the appellant (the accused rapist). Going by her evidence, it was the appellant who had nasty indecent assault on her. The evidence of her elder brother (P.W2), a child under 14years of age cannot, however corroborate her own evidence as both made unsworn testimonies"5

\section{Evidence of An Accomplice -}

An accomplice in a case of rape or other forms of sexual offence, is any person who pursuant to Section 7 of the Criminal Code as reproduced under chapter one hereinabove, may be deemed to have taken part in committing the offence as the defendant or as an accessory after the fact to the offence pursuant to section 10 of the Criminal Code but who is not him/herself charged or tried jointly with the defendant, the accused sexual offender. ${ }^{6}$

Under Section 198(1) which deals with the evidence of an accomplice, an accomplice shall be a competent witness against a defendant, and a conviction is not illegal merely because it is based on or proceeds upon the uncorroborated testimony of an accomplice. The section however has a provision which is of the effect that in cases when the only proof against a person with criminal offence, including sexual offences is the evidence of an accomplice, uncorroborated or which is not corroborated in any material particular implicating the defendant, the court shall direct itself that it is unsafe to convict any person upon such evidence. This also shows that corroboration is not required under the Evidence Act as a pre-condition for convicting an accused person upon the evidence of an accomplice. What the Evidence Act requires is that the Court directs and warns itself that it is unsafe to convict a person only on uncorroborated evidence of an accomplice. This notwithstanding, the Courts goes beyond directing and warning itself on the risk of convicting a person upon the uncorroborated testimony of one witness in rape cases and insists on corroboration in almost all cases of rape.

A review of decided cases on rape reveals that the courts look out for, consider and admit a number of evidence as corroborative evidence required by the practice of the courts to establish the commission of the offence of rape, namely: eye witness account of an independent witness (which is usually or almost impossible to come by $)^{7}$, medical report revealing penetration of the private part, medical evidence showing injury to the private part of the complainant or injury to other parts of the body of the victim which may have been occasioned in a struggle, seminal stains on the clothes of either the victim or the accused person or on both of


private part, vaginal laceration and/or blood stains, bruises, infection, torn clothes, confessional statement of the accused $^{9}$ or conduct of the accused ${ }^{10}$

The requirement of corroboration as a matter of law in certain sexual offences and as a practice of court even in those cases like rape where corroboration is not expressly required by the law posses great challenges in securing conviction on sexual offences and could create opportunities for some accused sexual offenders who ought to have been convicted to either escape punishment in its entirety or be convicted on lesser offences like attempt to commit rape or indecent assault. The case of Sambo v. State ${ }^{11}$ is a typical reference case. In Sambo $v$. State, the prosecution's case was that the appellant (the accused rapist), on the $2^{\text {nd }} \mathrm{July,} 1987$, requested the complainant (P.W.1, the victim of the rape), who was his neighbour, to fetch him water for bathing. When she brought the pail of water to the appellant's house, he invited her into his room, locked his door, and put on his music set. He then removed the child's dress, forced her on to his bed and tried unsuccessfully to put his private part (penis) on her private part (vagina). When the child started crying, he unlocked the door of his room and let




her go, pleading for her forgiveness so that "his name would not be spoiled". On getting home, P.W.1 took off her blood-stained pant and washed same.

When, later still, the sister (P.W.1) met her crying and asked her what was wrong with her, she told her what the appellant had done to her. On examination of her private part by P.W.2, she found some blood thereon. P.W.2 then made a report to the police which led to the arrest of the appellant. In the course of investigation, P.W.1 was sent to the General Hospital, Gombe, for examination which showed a kind of penetration of her private part, and statements were obtained from the appellant by the Police.

In his two statements to the police, the appellant admitted that he sent P.W.1 who is his neighbour to fetch "bathing water" for him. When she brought the water to his room, there was music being played on the radio and he began to dance with her. She however started crying, stating that she did not like what he was doing to her. He then left her and she departed. That at no time did he rape or force himself on her.

At the conclusion of hearing, the trial court convicted the appellant of lesser offence of attempted rape and indecent assault and sentenced him to a lesser terms of imprisonment. The appeal of the Appellant (the accused rapist) was dismissed by the Court of Appeal. The Supreme Court however allowed the appeal and reversed the judgments of the High Court and the Court of Appeal mainly on two grounds: First, that the evidence of the P.W.2, the sister of the victim, the evidence of the Police and the medical reports put together do not constitute corroborative evidence to the evidence of the victim and secondly, that the trial High Court failed to state in the records of proceedings how it arrived at the conclusion that enabled the court to accept the unsworn evidence of the prosecutrix (the alleged victim of the rape). In other words, that the trial High Court failed to carry out the preliminary investigations as envisaged under Sections 155, 180, and 182 of the old and repealed Evidence Act of 1990.

The pertinent questions that ought to have been asked and answered in favour of the victim and against the Appellant (the accused rapist) would have been that:

since it was the statement of the accused rapist that he indeed sent the little girl to fetch water for him and the little girl actually fetched the water to his house and he went further to be dancing with the girl in his room until the girl started complaining and crying that she did not like what he was doing to her, the consequential questions ought to have been:

(a) What attracted the accused rapist, a full grown man to be dancing with a little girl of 10 years in his private room?

(b) What was the nature of the dance that caused the girl to start crying?

(c) Apart dancing, what was it that the little girl referred to as an act that she did not like which the accused rapist was carrying out or doing to her?

(d) If the Appellant, accused rapist was merely dancing with the little girl, how come the girl was crying and complaining of something that the Appellant was doing to her?

(e) How come a mere dance caused bleeding in the private part of the little girl?

(f) How come there was evidence of some kind of penetration of the private part of the little girl?

(g) Looking at the voluntary statement of the Appellant, the accused rapist, what other nature of evidence did the Court require to believe the testimony of the little girl as cogent evidence that she was raped?

This is indeed the untoward effect of insisting on corroboration in sexual offences. It is strongly believed that in the light of the more recent cases of Ogunbayo v. State ${ }^{1}$, Popoola $v$ State ${ }^{2}$ and Ezigbo $v$ State ${ }^{3}$ the Appellant, and under such recent legislation as the Violence Against Persons Act, the accused rapist in the case of Sambo v. State 4 would have been convicted of rape with more severe sentence and punishment than was imposed on him by the trial court.

\section{Improvements in the Evidence Act, 2011 -}

The Evidence Act, 2011 which commenced on the $3^{\text {rd }}$ day of June, 2011 repealed the old Evidence Act, Cap E14, Law of the Federation of Nigeria, 2004 which was almost a reproduction of the previous Evidence Acts of 1945 and $1990 .^{5}$

A search through the length and breadth of the Evidence Act, 2011 shows that with the exception of Section 209(3) of the Evidence Act, 2011, which requires corroboration for unsworn evidence of a child of less than 14years of age, there is NO similar provision as Section 179(5) of the repealed Evidence Act or any other provision of the Evidence Act, 2011 which requires corroboration in sexual offences. What this means is that the

(2007) All FWLR (pt 365), 408 at 430

(2013) 17 NWLR (pt. 1382) p. 97

(2012) 16 NWLR (pt.1326). P. 318.

Ibid.

Section 257 of the Evidence Act, 2011. 
Evidence Act, 2011 has removed the requirement of corroboration in the prosecution of sexual offences in the Nigerian legal system. This is a progressively reformative step by our law makers in removing the hurdles and challenges of obtaining corroborative evidence in the prosecution of sexual offences whose absence (nonavailability of corroborating evidence) poses great difficulty to prosecutors in securing conviction for rape and other sexual offences.

\section{Implications of the Removal of Corroboration -}

From the view point of the legislature and the general public, the absence of the requirement for corroboration in sexual offences, except in respect of unsworn testimony of a child of less than 14 years under the Evidence Act, 2011, persons prosecuted for rape and other sexual offences can be convicted upon the uncorroborated but cogent evidence of one witness who could be the prosecutrix, the victim of the rape. However, with the traditional precautionary practice of the Courts in insisting on corroboration as a practice of the Court, and not as a matter of statutory requirement, the exit of corroboration in the prosecution and adjudication of rape and other sexual offences may not be on sight.

Be that as it may, it is expected that our courts will in practice, relax or jettison the old rule of insisting on corroboration in sexual offences and convict and sentence the offenders upon credible and cogent testimony or evidence of one witness, especially the victim who, most times, suffer the animalistic, barbaric and beastly act of rape and/or other forms of sexual violence without the opportunity of having another witness. Better still; the courts are urged to loosen the parameters of what they consider as corroborative evidence and in apposite cases, convict with cogent evidence of one witness with or without corroboration.

It is also expected that parts of Sections 218, 221, 223, 224, 275 and 282(1)(e) of the Criminal and Penal Code which requires corroboration in their substantive provisions be abrogated to align them with the improvements in the Evidence Act, 2011.

\section{Questions Tending To Show Immoral Character of Victims -}

One of the major challenges faced by most victims of rape and other sexual offences in our Nigerian society which goes to the extent of discouraging them from reporting their cases for investigation and prosecution is the embarrassments they usually receive from people including the law enforcement agents. Most people in our society tend to find fault with victims of rape and other sexual offences and expect them to prove their innocence instead of sympathizing with them and helping them to get justice as innocent victims of wicked acts of sexual violence.

Most times, they are embarrassed with questions tending to show that they are persons of immoral character with the likelihood to consent to any form of sexual connection with another person and as such should not be heard to complain of any form of sexual violence. This unfortunately uninformed public perception of victims of rape and other sexual offences imposed on the victims, the syndrome of preferring to suffer and die in silence instead of reporting their cases, only to face public embarrassments and the stigmatization that usually go with it.

Surprisingly, the old Evidence Acts ${ }^{1}$ had provisions which allowed questions to show the past sexual life of a victim of rape or indecent assault in order to possibly contradict the victim in a given current case of rape or indecent assault.

Specifically, Section 211 of the old and repealed Evidence Act, Cap E14, 2004 provided as follows:

"When a man is prosecuted for rape or for attempt to commit rape or indecent assault, it may be shown that the woman against whom the offence is alleged to have been committed was of a generally immoral character, although she is not cross-examined on the subject. The woman may in such a case be asked whether she has had connection with other men, but her answer cannot be contradicted and she may also be asked whether she has had connection on other occasions with the perpetrator, and if she denies it, she may be contradicted."

The above section of the old Evidence Act assumes that a woman or a girl who has in the past, had sexual intercourse with other men or with an accused person will likely give consent to sexual intercourse or any sexual act in a particular case where she alleges rape or any other form of sexual violence.

The above provision of the old Evidence Act could be faulted on three grounds. First, it should be only when the debauchment, defilement or deflowering of a girl or woman is the fact in issue that the question of whether she has had sexual intercourse in the past with any man or with the accused becomes relevant. Secondly, it is unacceptable that a woman or girl adjudged to be of immoral character should no longer have any option or choice as to when and with whom she could engage in sexual intercourse. Thirdly, every act of sexual intercourse requires the exercise of the freewill and informed consent of the parties. It is therefore wrong, oppressive, vindictive, hasty and unacceptable to assume or hold that a woman or girl who has had sexual

Cap. 112, Laws of the Federation of Nigeria (LFN), 1990; Evidence Act, Cap 62, 1945 and Evidence Act, Cap E14, LFN, 2004. 
intercourse with a man in the past should continue or will be expected to continue in the practice whether or not she accepts it.

In respect thereof, some writers have reacted and rightly in our view thus:

"That a woman is loose morally is not a ticket for her to be raped. She still reserves the choice to choose who she wants to 'bestow her favours on'. Allowing her previous sexual record to be an issue in trial where she is alleging she was raped is like saying, 'since you have been doing it with others, you could as well have done it with this one'. Without sounding as if one is condoning immorality, it begs the question to say that a woman's sexual history should be used to determine whether she was raped or not."1

This writer share the view that Section 211 of the old Evidence Act was capable giving opportunities to defendants and their Counsel/lawyers to run down and completely embarrass victims of sexual violence and discourage them from crying out loud for justice. It is therefore humbly submitted that the section was irrelevant. Its main objective, especially the first part of the section which touches on the sexual life of the victim with other men, was to embarrass victims of rape and indecent assault. It was capable of creating room for women or girls adjudged to be of immoral character to be sexually violated without getting the strict legal intervention.

\section{Improvements in the Evidence Act, 2011 -}

The Evidence Act, 2011 has made tremendous improvements towards seeking to save victims of rape and indecent assault from the irrelevancies and ridicule associated with the old Evidence Act, and has made the following provisions in its Section 234 which states that: "Where a person is prosecuted for rape or attempt to commit rape or for indecent assault, except with leave of the Court, no evidence shall be adduced, and, except with the like leave, no question in cross-examination shall be asked by or on behalf of the defendant, about any sexual experience of the complainant with any person other than the defendant".

Notably, this section of the Evidence Act excludes or prohibits any question which would seek to expose the sexual life of the victim with other men except the defendant alleged to have raped the victim in a given case. This is commendable as it will help to keep away from public exposure, the private sexual life between the victim and other men in the course of prosecuting a particular sex crime case.

With respect to questions that may touch on the past sexual experience of the victim and the defendant in a given case, the Section recognizes the power and wisdom of the judges to scrutinize such questions and ascertain their relevance to the case at hand before allowing the question to the victim. This is to ensure that alleged sexual offenders do not in the course of trial, ask irrelevant questions that will unnecessarily embarrass and possibly worsen the trauma of an already traumatized victim of sexual violence who is in court to seek justice. It is however recommended that Section 234 of the Evidence Act, 2011 should be applied more in determining the sentence or punishment to be imposed on defendant than in using the section to presume the likelihood of consent on the part of the victim so as to let the offender off the hook.

The provision of Section 234 of the Evidence Act is further straightened by Sections 227 and 228 dealing on needlessly offensive, unreasonable, annoying, indecent and scandalous questions. The sections provide thus: Section 227: "The Court may forbid any questions or inquiries which it regards as indecent or scandalous although such questions or inquiries may have some bearing 'on' the questions before the Court, unless they relate to facts in issue or to matters necessary to be known in order to determine whether or not the facts in issue existed."

Section 228:

"The Court shall forbid any question which appears to it to be intended to insult or annoy, or which, though proper in itself, appears to the Court needlessly offensive in form"

It is strongly hoped that a combination of the improvements in the Evidence Act, 2011 with the other measures in the Administration of Criminal Justice Act, 2015, as highlighted below, will go a long way to protect victims of sexual violence and thereby, encourage them to cry out loud and seek justice without fear of more scandals, unnecessary embarrassment, stigmatization and humiliations in the course of seeking justice.

\section{Enhanced Remedies and Protections for Victims of Rape and other Sexual Violence and their Witnesses under the Administration of Criminal Justice Act, 2015. Administration of Criminal Justice Act, (ACJA), 2015 -}

The Administration of Criminal Justice Act came into force in Nigeria in 2015. The purpose of the Act among other things is to ensure that the system of administration of criminal justice in Nigeria promotes efficient management of criminal justice institutions, speedy dispensation of justice, protection of the society from crime and protection of the rights of the suspect, the defendant, and the victim. ${ }^{2}$

\footnotetext{
$1 \quad$ Caroline O. Oba, “The Prosecution of Rape in Nigeria: An Agenda for Reform” Justice Journal, A Journal of Contemporary Legal Issues, (Federal Ministry of Justice, Abuja), vol. 4, 2012 p. 105. Part 1, Section 1 of the Act.
} 
The ACJA, 2015 repeals the Criminal Procedure Act Cap. C41 Laws of the Federation of Nigeria, 2004, Criminal Procedure (Northern States) Act Cap. C42 Laws of the Federation of Nigeria, 2004, and the Administration of Justice Commission Act Cap.A3 Laws of the Federation of Nigeria, 2004. The Act applies to criminal trials for offences, including rape and other sexual offences ${ }^{1}$, established by an Act of the National Assembly (called federal offences) and other offences punishable in the Federal Capital Territory, Abuja. ${ }^{2}$ The federating States are expected to adopt the Act in their various States. ${ }^{3}$

Recognizing the need to legally provide for better remedies to victims of crime, including rape and other sexual offences and also protect the victims and their witnesses in course the of trial, the Administration of Criminal Justice Act, 2015 has made the following provisions which were hitherto, not available in our criminal justice system:

\section{Enhanced Remedies For The Victims:}

Section 314 (1): Notwithstanding the limit of its civil or criminal jurisdiction, a court has power, in delivering its judgment, to award to a victim commensurate compensation by the defendant or any other person or the State.

The legal implication of the opening phrase "Notwithstanding the limit of its civil or criminal jurisdiction," in relation to the other parts of the subsection is to the effect that a court giving or delivering judgment in a criminal matter is empowered to award any sum of money as it may deem fit as compensation in favour of the victim of the crime whether or not such amount of compensation awarded is above the limit the court can award as a matter of its normal jurisdiction. An illustration of section 314(1) of the ACJ Act can be made as thus:

In the FCT Abuja, Magistrate Courts have both civil and criminal jurisdictions. A Magistrate Court sitting on its criminal jurisdiction retains its designation or name as "Magistrate Court". When sitting on its civil jurisdiction, the Court is known as a District Court. In relation to the upper limits of the District Courts in the FCT Abuja, A Chief District Judge I can entertain and award compensation in a civil matter or cause up to the upper limit of \#5, 000,000.00. ${ }^{4}$ Chief District Judge II can also award compensation in civil matters or causes up to the upper limits of $\# 4,000,000.00 ; \# 3,000,000.00 ; \# 2,000,000.00$ and $\# 1,000,000.00$ respectively. ${ }^{5}$ The argument and expectation will be that going by the upper limits of the Magistrate Courts in exercise of their civil jurisdiction (as District Courts), the maximum compensation that may be awarded by the Magistrate Courts in exercise of their criminal jurisdiction as such, ought not exceed their upper limits in civil jurisdiction since award of compensation in criminal proceedings is likened to what obtains in the civil proceedings. The implication of section 314(1) of the ACJ Act 2015 is that a magistrate court in its criminal jurisdiction can award a sum of money as compensation to a victim of crime over and above its upper limits as the court may deem fit in delivering its judgment in a criminal proceedings.

Section 314(2): $\quad$ The Court in considering the award of compensation to the victim may call for additional evidence to enable it determine the quantum of compensation to award in subsection (1) of this section.

Section 319 (1): A court may, within the proceedings or while passing judgment, order the defendant or convict to pay a sum of money:

(a) as compensation to any person injured by the offence, irrespective of any other fine or other punishment that may be imposed or that is imposed on the defendant or convict, where substantial compensation is in the opinion of the court recoverable by civil suit;

(b).............

(c) in defraying expenses incurred on medical treatment of a victim injured by the convict in connection with the offence.

(3): $\quad$ Order for cost or compensation may be made under this section irrespective of the fact that no fine has been imposed on the defendant in the judgment.

In a similar provision under the Criminal Procedure Code, Section 365(1) of the Code had the provision as follows:

"Whenever under any law in force for the time being a criminal court imposes a fine, the court may, when passing judgment, order that in addition to a fine, a convicted person shall pay a sum - "

The Federal Acts creating the offence of rape and the sexual offences includes the Child's Rights Act, the

Criminal Code Act, The Penal Code Act, the Violence Against Persons (Prohibition) Act, 2015, the Trafficking in Persons (Prohibition) (Enforcement and Administration Act), 2015.

Part 1, Section 2 of the Act.

Lagos State and Anambra State Administration of Criminal Justice Law already predates the

Administration of Criminal Justice Act. Enugu State is already on the process of having the law.

District Courts (Increase in Jurisdiction of District Judges) ORDER, 2014 which came into force on the $14^{\text {th }}$

day of February, 2014.

Ibid. 
Section 365(1)(b) -

"in compensation in whole or in part for the injury caused by the offence committed, where substantial compensation is in the opinion of the court recoverable by civil suit".

In interpreting the old Criminal Procedure Code, it is to say that compensation under the section follows the imposition of fine and where fine is not imposed of the convict; the victim of the crime shall not be entitled to compensation under the section.

A close look at Section 319 (1)(a) shows an improvement to what Section 365(1) of the Criminal Procedure Code provided. This is appreciated in the reading of Section 319(1)(a) of the ACJA 2015 that:

"A court may, within the proceedings or while passing judgment, order the defendant or convict to pay a sum of money as compensation to any person injured by the offence, irrespective of any other finel or other punishment that may be imposed or that is imposed on the defendant or convict, where substantial compensation is in the opinion of the court recoverable by civil suit;

This shows that while the imposition of fine on the convict is a precondition for an order for award of compensation to the victim of the offence under section 356(1) of the Criminal Procedure Code, there is not such condition under Section 319(1)(a) of the AJCA. Thus, once the court is of the opinion that a substantial compensation can be recovered by the victim of the crime through a civil suit, the Court may award any amount or quantum of compensation to the victim of the offence against the convict, irrespective of any other fine ${ }^{2}$ or other punishment that may be imposed on the defendant or convict. That is to say, whether or not any other fine or punishment is imposed on the convict and notwithstanding what the fine or any other punishment may be or may have been imposed on the convict or the defendant, the victim can be awarded compensation by the courts under the ACJA 2015.

Section 320(1):

At the time of awarding compensation in any subsequent civil suit relating to the same mater, the court shall take into consideration, any sum paid or recoverable as compensation under this section.

Section 321:

A court after conviction may adjourn proceedings to consider and determine sentence for each convict:

(a) in addition to or in lieu of any other penalty authorized by law, order the convict to make restitution or pay compensation to any victim of the crime for which the offender was convicted, or to the victim's estate; or

(b).

In order to enforce the payment of the compensation as may be awarded by the court in favour of the victims and their estates, the Act went further in Sections 325 and 326 to provide as follows:

Section 325: Any compensation ordered to be paid under this Act or any other Act, relating to any criminal proceedings, may be enforced as if it were a fine.

As noted earlier, other Acts creating criminal offences under which compensation may be paid to the victims of the crime include the Violence Against Persons Act, $2015^{3}$ and the Trafficking in Persons (Prohibition) (Enforcement and Administration) Act, 2015. ${ }^{4}$

Section 326(1):

Where a convict is ordered to pay fine, or a defendant is ordered to pay compensation to another person under section 319 of this Act, or a person is subject to recovery of penalty for forfeiture of a bond under this Act, the Court passing the sentence or making the order may, notwithstanding that, in default of the payment of the fine or compensation or penalty, the convict or defendant may be imprisoned, issue a warrant for the levy of the amount by any means permitted by law, including:

(a) the seizure and sale of any moveable property belonging to the defendant or convict;

(b) the attachment of any debt due to the defendant or convict; and

(c) subject to the provisions of the Land Use Act, the attachment and sale of any immovable property of the convict situated within the jurisdiction of the Court.

(2): A warrant for seizure and sale of the movable property of a person under this section shall be addressed to the Court within whose jurisdiction it is to be executed.

(3): Where execution of warrant is to be enforced by attachment of debts or sale of immovable property, the warrant shall be sent for execution to any court competent to execute orders for payment of money in civil suits and the court shall follow the procedure for the time being in force for execution of such orders.

Before the enactment of the ACJA, 2015, the Courts under the Nigerian criminal justice system had highly limited powers to order for compensations and restitution in favour of victims of crimes as a part of the Criminal 
Proceedings. The provisions were only with Sections 360, 365, 371 of the Criminal Procedure Act. Those provisions aside, fines imposed on convicts went to the state since every criminal offence, including offences against individual persons was dealt with as crime against the State. The victims who directly suffered the actions of the convicts were expected to feel pacified or assuaged with the punishment of imprisonment and/or fines imposed on the convicts. Any victim who desired compensation was expected to institute civil actions in Court for a civil remedy. Victims who do not have the wherewithal to take civil action or who could not obtain legal aid services submitted to fate groaning without any remedy directly accruable to them from all they may have suffered as a result of the crime against them.

The provisions for compensation and restitution in the Administration of Criminal Justice Act are therefore highly welcomed innovation. They are in agreement with Section 1(3) of the VAPP Act, 2015 which mandates the court to award appropriate compensation to the victim of rape as the court may deem fit in the circumstance ${ }^{1}$. Besides imposing prison terms and/or fines on the convicts, the practical application of the provisions of the ACJA on compensation and restitution in dealing with cases of sexual violence is sure to attract some degree of succor to Victims of rape and other acts of sexual violence who suffer physical and psychological injuries and pains and/or have their wears torn in the course of the forceful sexual intercourse and incur medical expenses and other costs in respect thereof. The provisions will also be of benefits to families of the victims who may, very unfortunately die in the course of the sexual violence.

\section{Protection of persons Against False Accusation -}

The ACJA is not unaware of situations where false allegation could be brought against innocent persons alleging that they committed criminal offence, including rape and other sexual offences. To protect their interests and compensate them for such false accusation, the ACJA has made the following provisions in Section 323 of the ACJA:

Section 323(1):

"Where a causes the arrest, or arrest and charge of a defendant or defendants and it appears to the court that there was no sufficient ground for causing the arrest, or that the accusation is false, vexatious or frivolous, it may for reason recorded, order the person to pay reasonable compensation to the defendant or defendants arrested and charged"

Section 323(2): "The Court may, in default of payment of such compensation or any part of it, award a term of imprisonment against the person against whom the order was made, for any term not exceeding the term prescribed in respect of a like sum in the scale of imprisonment set out in this Act or the Court may sentence the person to Community Service in accordance with Section 462 of this Act."

The above provisions are also in agreement with Sections 125 and 125A of the Criminal Code Act which makes it a felonious punishable crime for any person to bring or raise false accusation or conspire with another person to falsely accuse or bring false accusation or false allegation against an innocent person.

However, while the Criminal Code provides for terms of imprisonment as the only punishment for false accusation and conspiracy to raise or bring false accusation against an innocent person, the Administration of Criminal Justice Act, 2015 remarkably improved on the provisions against false and vexatious accusation by providing for compensation to the person falsely accused with possible imprisonment or Community Service against the false accuser in default of payment of the compensation.

The lesson there is for any person raising alarm or bringing up a case of such serious nature as rape, defilement, indecent assault, sexual exploitation and any other form of sexual violence to be sure he/she is not raising a deliberately, intentionally or recklessly false allegation.

\section{Protection of Victims and Their Witnesses -}

Section 232(1): $\quad$ A trial for the offences referred to in subsection (4) of this section may not, where the court so determines, be held in an open court.

(2): The names, addresses, telephone numbers and identity of the victims of such offences or witnesses shall not be disclosed in any record or report of the proceedings and it shall be sufficient to designate the names of the victims or witnesses with a combination of alphabets.

(3): Where in any proceedings the court deems it necessary to protect the identity of the victim or a witness, the court may take any or all of the following measures:

(a) Receive evidence by video link;

(b) Permit the witness to be screened or masked;

(c) Receive written deposition of expert evidence; and

(d) Any other measure that the court considers appropriate in the circumstance.

\footnotetext{
$1 \quad$ Section 65 (3) of the Trafficking in Persons (Prohibition) (Enforcement and Administration Act, 2015.
} 
In section 232 subsection (4), the offences to which the section applies as listed in section 231 of the Act are rape, defilement, incest, and unnatural or indecent offences against person. The section also applies to trial of offences under the Trafficking in Persons which includes sexual exploitation and other related offences. Others include terrorism cases, financial crimes cases and any other offence as an Act of the National Assembly may require or as the judge may deem fit to apply such measures in any case.

In subsection(5) of section 232, the Act went further to make it an offence punishable with a minimum of 1year imprisonment for person convicted of contravening subsection (2) of the section dealing on non-disclosure of the identities of the victims and the witnesses.

Notably, sections 154(3), 155 - 158, 205 of the Child's Rights Act dealing on the protection of child victims, Section 32 of the VAPP Act which stipulates certain duties of the police for the protection of victims of violence and sections 38 and 39 of the same VAPP Act which deals on the rights of victims of acts of violence, and the protection of victims and witnesses and Sections 46, 47 of the Trafficking in Persons (Prohibition) (Enforcement and Administration) Act, 2015 on protection of informants, witnesses and treatment of victims of trafficking all share similar objects which is the protection of victims and witnesses. It is hoped that the strict application of the above relevant provisions of the ACJ Act, THE VAPP Act, TIPPEA Act and other similar provisions in other laws by our Courts is sure to go a long way to create a sense of security for our people and provide the enabling environment for the entire society, especially victims of sexual violence and witnesses to cry out loud against the crime and seek justice.

\section{Improvements In Line With the ICTY and ICTR?}

The Rules of Procedure and Evidence for the International Criminal Tribunal for Rwanda (ICTR) are a set of rules made for the International Criminal Tribunal (ICT) for the prosecution of persons responsible for genocide and other serious violations of International Humanitarian Law committed in the territory of Rwanda. It also applies to Rwandan citizens responsible for genocide and other such violations committed in the territory of neighboring states, between January 1, 1994 and December 31, 1994. The Tribunal was established by the United Nations Security Council Resolution 955 of 8th November, 1994. The ICTR Rules of Procedure and Evidence was adopted pursuant to Article 14 of the Statute of the Tribunal and the Rules entered into force on 29th June, $1995 .^{1}$

Similarly, the Rules of Procedure and Evidence of the International Criminal Tribunal for the former Yugoslavia (ICTY) are a set of rules made for the International Criminal Tribunal (ICT) for the prosecution of persons responsible for serious violations of international humanitarian law committed in the territory of the former Yugoslavia since 1991. The Tribunal was also established by the United Nations Security Council Resolution 827 of 25th May, 1993. The ICTY Rules of Procedure and Evidence was adopted pursuant to Article 15 of the Statute of the Tribunal and the Rules entered into force on $14^{\text {th }}$ March, $1994 .^{2}$

The ICTR and ICTY Rules of Procedure and Evidence cover cases of sexual assault, including rape, protection of victims and witnesses similar to the improvements in the Nigerian substantive and procedural laws. The relevant rules being Rules 90, 96, 34, 69, 75 of the ICTY and ICTR Rules and Article 68 of the Rome Statute are considered hereunder to appreciate how the improvements so far made in the Nigerian laws align with or agree with those international standards.

Rule 90 (A) and (B) of the ICTY Rules of Procedure and Evidence provide:

Rule 90 (B): $\quad$ Every witness shall, before giving evidence, make the following solemn

Declaration: "I solemnly declare that I will speak the truth, the whole truth and nothing but the truth".

Rule 90(C): $\quad$ A child who, in the opinion of the Chamber, does not understand the nature of a solemn declaration, may be permitted to testify without that formality, if the Chamber is of the opinion that the child is sufficiently mature to be able to report the facts of which the child had knowledge and understands the duty to tell the truth. A judgment however, cannot be based on such testimony alone. ${ }^{3}$

It is noteworthy that Rule 90(B) and (C) of the ICTR Rules has the same wordings and provision with Rule 90(A) and (B) of the ICTY Rules of Evidence and Procedure. Clearly, Rule 90(B) of the ICTY Rules and 90(C) of the ICTR Rules require corroboration of the evidence of a child who is not administered the solemn declaration because, in the opinion of the Chamber, the child does not understand the nature of a solemn declaration, but the Chamber is however of the opinion that the child is sufficiently mature to be able to report the facts of which the child had knowledge and understands the duty to tell the truth. These provisions of Rule 90(B) of the ICTY Rules and 90(C) of the ICTR Rules are similar to section 209(3) of the Evidence Act of Nigeria, 2011. Interestingly, the ICTR and ICTY Rules do not require corroboration even of the unsworn

This is the amendment to the rule effected on 30 January 1995. 
evidence of a child in rape cases and all cases of sexual assault or violence. Accordingly, Rule 96 of ICTR Rules of Evidence and Procedures provides:

Rule 96 of the Rules provides as follows:

"In cases of sexual assault;

(a) No corroboration of the victim's testimony shall be required"

(b) Consent shall not be allowed as a defence if the victim:

(i) Has been subjected to or threatened with or has had reason to fear violence, duress, detention, or psychological oppression; or

(ii) Reasonably believed that if the victim did not submit, another might be so subjected, threatened or put in fear;

(c) Before evidence of the victim's consent is admitted, the accused shall satisfy the trial chamber in camera that the evidence is relevant and credible;

(c) Prior sexual conduct of the victim shall not be admitted in evidence.

The absence of the requirement for corroboration in the Evidence Act of Nigeria, 2011 except less than 14years of age, is in agreement with Rule 96(a) of the ICTY Rules.

The language of all the sections of the Nigerian laws on rape which do not admit consent obtained by fear, duress, coercion, threat, intimidation and the likes as genuine consent required for sexual intercourse are within the concerns of Rule 96(b)(i)(ii) of the Rules. It is also no doubt that the Courts in Nigeria consider the circumstances captured in 96(b)(i)(ii) including 96(c) of the ICTY Rules in determining or arriving at a finding of fact as to whether or not the victim consented to the sexual intercourse.

Although section 234 of the Evidence Act, 2011 is an improvement on the previous and repealed Evidence Acts in that the section does not make provision for and therefore does allow questions relating to past sexual experience of the victim with other men, section 234 of the Evidence Act, 2011 is not totally in line with Rule 96(d) of the ICTY Rules. This is because, while Rule 96(d) of the ICTY Rules prohibits any question relating to the past or prior sexual conduct of the victim with any person, including the accused, Section 234 of the Evidence Act, 2011 still allows questions that may relate to the past sexual life of the victim with the accused person. The only safeguard therein for the victim is that such question can only be asked with the leave of court. It is submitted by this writer, that Rule 96(d) of the ICTY Rules is preferred vis-à-vis section 234 of the Evidence Act, 2011. This is so because; a person has and should be allowed to have absolute right of choice over his/her sexual life. Consent to sexual intercourse ought to be sought for and a person ought not to be allowed to find its ways to the prosecution of any person standing trial for the offence of rape or any other sexual offence at any given time.

Since section 234 of the Evidence Act, 2011 does not allow a question seeking to show a prior sexual experience of a victim of sexual violence with the accused person without the leave of Court, this writer humbly urge the Courts to exercise much self restraint in granting such leave. This will help to protect the victim from embarrassment and to preserve and advance the right of consent to sexual intercourse at any given time without giving room for the past sexual life of a victim to interfere with his/her right to consensual intercourse.

Rule 34 A of the ICTY Rules states that:

(i) Recommend protective measures for victims and witnesses in accordance with Article 22 of the Statute; and

(ii) Provide counseling and support for them, particularly in cases of rape and sexual assault.

Article 22 of the ICTY Statute referred to in Rule 34A above makes provision for the protection of victims and witnesses by directing possible holding of proceedings in camera, non disclosure and protection of the identity of victims.

Similarly but more broadly, Rule 34A of the ICTR Rules provides that:

There shall be set up under the authority of the Registrar, a Victims and Witnesses Support Unit consisting of qualified staff to:

(i) Recommend the adoption of protective measures for victims and witnesses in accordance with Article 21 of the Statute.

(ii) Ensure that they receive relevant support, including physical and psychological rehabilitation, especially counseling in cases of rape and sexual assault; and

(iii) Develop short term and long term plans for the protection of witnesses who have testified before the tribunal and who fear a threat to their life, property or family.

Article 21 of the Statute referred to in 34A (i) above is similar to Article 22 of the ICTY Rules.

Article 68 of the Rome Statute -

Article 68 of the Rome Statute established in the International Criminal Court, ICC. The ICC has been conferred with the jurisdiction to try the most serious crimes of international concern. ${ }^{1}$

Article 1 of the Rome Statute. In article 5 of the Statute, the crimes of International concern which the ICC has jurisdiction to try include the crime of genocide, crimes against humanity, war crimes and crime of aggression. 
Article 68 of the Rome Statute has the following provisions on the protection of victims and witnesses:

1. The Court shall take appropriate measures to protect the safety, physical and psychological wellbeing, dignity and privacy of victims and witnesses. In so doing, the Court shall have regard to all relevant factors, including age, gender, as defined in Article 7 paragraph, and health, and the nature of the crime, in particular, but not limited to, where the crime involves sexual or gender violence against children. The prosecutor shall take such measures particularly during the investigation and prosecution of such crimes. These measures shall not be prejudicial to or inconsistent with the rights of the accused and a fair and impartial trial.

2. As an exception to the principle of public hearings provided for in Article 67, the Chambers of the Court may, to protect victims and witnesses or an accused, conduct any part of the proceedings in camera or allow for presentation of evidence by electronic or other special means. In particular, such measures shall be implemented in the case of a victim of sexual violence or a child who is a victim or a witness, unless otherwise ordered by the Court, having regard to all the circumstances, particularly the views of the victims and witness.

3. Where the disclosure of evidence or information pursuant to this statute may lead to the grave endangerment of the security of a witness or his or her family, the prosecutor may, for the purpose of any proceedings conducted prior to the commencement of the trial, withhold such evidence or information and instead submit a summary thereof. Such measures shall be exercised in a manner which is not prejudicial to or inconsistent with the rights of the accused and a fair and impartial trial.

It is worthy of note that Rules 34A of the ICTY and ICTR and Article 68 of the Rome Statute provides measures for counseling, physical and psychological rehabilitation of victims and the protection of witnesses who had testified before the tribunal and are under fear of threat to their life, property and family. On the part of the Federal Republic of Nigeria, recent legislative interventions, especially at the level of the National Assembly shows that Nigeria has advanced as well in the areas covered by Rule 34A of the ICTY and ICTR Rules of Procedure and Evidence and Article 68 of the Rome Statute which established the International Criminal Court (ICC).

\section{Conclusion -}

A reading of section 232 and with reference to section 231 of the Administration of Criminal Justice Act of Nigeria, 2015 on the protection of victims and witnesses shows that the section are in line with the concerns of Rules 34, 69, and 75 of the ICTR and ICTY Rules of Procedure and Evidence and Article 68 of the Rome Statute. Notably also, Section 227 of the Evidence Act of Nigeria, 2011 share similar concerns with Rule 75(C) of the ICTY and ICTR Rules.

In addition, different substantive law provisions such as Sections 154(3), 155 - 158, 205 of the Child's Rights Act dealing on the protection of child victims, Section 32 of the VAPP Act on certain duties of the police for the protection of victims of violence and sections 38 and 39 on the rights of victims of acts of violence, and the protection of victims and witnesses and Sections 46, 47 of the Trafficking in Persons (Prohibition) (Enforcement and Administration) Act 2015 on protection of informants, witnesses and treatment of victims of trafficking are all improvements and innovations in the substantive laws of Nigeria in line with the ICTY and ICTR Rules of Procedure and Evidence on the protection of victims of crimes and the witnesses. It is expected that the relevant authorities like the Courts, the police and the NAPTIP responsible for giving effect to these progressive provisions of our laws in Nigeria will deepen the efficacy of the law through meaningful and expansive interpretation to the benefit of victims and witnesses. Doing such is sure to encourage the victims of rape and other forms of sexual assault to cry out loud for justice and resist the culture of dying in silence. 